Beata ROSICKA

Uniwersytet Ekonomiczny we Wrocławiu

\title{
WPŁYW NAGŁOŚNIENIA POSZUKIWAŃ „ZŁOTEGO POCIĄGU“ NA RUCH TURYSTYCZNY W WAŁBRZYCHU I OKOLICACH
}

\section{Wprowadzenie}

W okresie intensywnego przepływu ludności na świecie, ułatwionego dostępu do dóbr oraz rozwiązań komunikacyjnych turystyka stała się istotnym czynnikiem napędzającym rozwój gospodarczy zarówno o zasięgu lokalnym, jak i ogólnoświatowym. Jednakże funkcja turystyczna może w każdej jednostce samorządu terytorialnego mieć zupełnie inne znaczenie - od marginalnego po priorytetowe. Istotę turystyki warunkuje chociażby wielkość danej miejscowości, gdyż przyjmuje się, że w małych jednostkach przestrzennych ma ona większy wpływ na rozwój lokalnej gospodarki turystycznej niż w dużych ośrodkach (DEREK, KOWALCZYK, SWIANIEWICZ 2005). $\mathrm{Z}$ pojęciem turystyki nierozerwalnie związane jest także zjawisko ruchu turystycznego, który generowany jest bezpośrednio przez atrakcje turystyczne. W literaturze przedmiotu występuje wiele definicji opisujących owe zjawisko. A. Panasiuk definiuje ruch turystyczny jako społeczny proces polegający na podróżowaniu ludności do regionów o charakterze turystycznym, z aspektów zarówno zawodowych, kulturowych, jak i społecznych. Charakterystyczne dla tego zjawiska jest to, że przemieszczanie się i zmiana miejsca stałego zamieszkania są dobrowolne oraz tymczasowe. Należy zaznaczyć, że 
ruch turystyczny bezpośrednio oddziałuje na sytuację ekonomiczną oraz społeczno-gospodarczą danej jednostki samorządu terytorialnego, gdyż każde jego wahanie wywołuje podobne zmiany we wskazanych sferach (PANASIUK 2006). Zgodnie z definicjami przyjętymi przez zagranicznych teoretyków, głównymi cechami ruchu turystycznego są jego społeczny charakter, który prowadzi do podejmowania podróży w celach poznawczych, kulturowych, rekreacyjnych oraz wypoczynkowych (GAWORECKI 2010), a nieprzewidywalność (AWEDYK 2015), przy czym element ryzyka i pojawienie się nowych trendów, powinny być brane pod uwagę przez podmioty gospodarki turystycznej. Wynika z tego, że wzmożony ruch turystyczny może być także wywołany niespodziewanymi wydarzeniami pobudzającymi ciekawość ludzi. Wśród takich wydarzeń należy wskazać nagłośnienie w sierpniu 2015 roku domniemanego odnalezienia w okolicach zamku Książ w Wałbrzychu tzw. złotego pociągu z II wojny światowej.

Niniejsze opracowanie jest zatem próbą scharakteryzowania wpływu jednego z ważniejszych wydarzeń medialnych z sierpnia 2015 roku - przypuszczalnego odkrycia niemieckiego pociągu pancernego na ruch turystyczny w atrakcjach turystycznych utworzonych $w$ miejscach związanych bądź utworzonych $\mathrm{w}$ czasie II wojny światowej w Wałbrzychu i okolicach. Ponadto $\mathrm{w}$ pracy zaproponowano działania, które powinny zostać podjęte w celu utrzymania zainteresowania mediów i turystów badanym obszarem.

\section{Charakterystyka atrakcji turystycznych z czasów II wojny światowej w Wałbrzychu i okolicach}

W czasie II wojny światowej w północno-zachodniej części Gór Sowich oraz na Pogórzu Wałbrzyskim rozpoczęto na dużą skalę prace górnicze i budowlane, których zamierzeniem było stworzenie połączonego ze sobą systemu obiektów składających się z części podziemnych i naziemnych. Dotąd nie wyjaśniono jednoznacznie przeznaczenia całego przedsięwzięcia. Znane dotychczas dokumenty wskazują na to, iż mogła być to budowa zespołu podziemnych fabryk zbrojeniowych bądź kwatery dla Naczelnego Dowództwa III Rzeszy. Całe przedsięwzięcie otrzymało kryptonim „Riese” (z języka niemieckiego, po polsku oznaczającego "Olbrzym") i pod tą nazwą występuje do dzisiaj (CERA 1998). Budowano równocześnie co najmniej siedem obiektów: Włodarz, Osówkę, Rzeczkę, Jugowice Górne, Soboń, Gontowę, a także 
podziemia pod Książem. W czterech z nich zostały utworzone podziemne trasy turystyczne. Znane dotychczas zespoły podziemnych wyrobisk liczą łącznie około $8100 \mathrm{~m}$ długości, mają $26000 \mathrm{~m}^{2}$ powierzchni oraz $97500 \mathrm{~m}^{3}$ objętości (KRUSZYŃSKI 1998).

Pierwszym z obiektów, w którym w 1995 roku utworzono podziemną trasę turystyczną są Sztolnie Walimskie w Rzeczce. Łączna długość zinwentaryzowanych wyrobisk wynosi $500 \mathrm{~m}$ (ANISZEWSKI 2002). Jest to jedyny z obiektów "Riese” w całości udostępniony turystom. Czas zwiedzania wynosi około 45 minut. We wnętrzu przygotowano wystawy tematyczne „Podziemny przemysł zbrojeniowy III Rzeszy”, "Minerały Gór Sowich” oraz "Obozy pracy AL Riese 1943-1945". Ponadto turyści przenoszą się w chodnikach dźwiękowych do 1945 roku oraz stają się świadkami nalotu bombowego na podziemia. Drogę główną, prowadzącą z Walimia do Sokolca, połączono z obiektem, kładką wykonaną $\mathrm{z}$ elementów mostu saperskiego Bailey'a typu 80-22, przygotowano trzy parkingi dla autokarów i samochodów osobowych oraz wybudowano pawilon obsługi turystów (CHYLIŃSKA 2006). Od 1 stycznia 2008 roku gestorem trasy turystycznej jest samorządowa instytucja kultury Centrum Kultury i Turystyki w Walimiu.

Drugim obiektem udostępnionym do zwiedzania od 5 marca 1996 roku jest Podziemne Miasto Osówka w Sierpnicy koło Głuszycy. Do części podziemnej prowadzą trzy sztolnie położone przy leśnej drodze prowadzącej z Kolc do Walimia (KRUSZYŃSKI 1998). Zwiedzający mają do wyboru cztery trasy zwiedzania: historyczną, ekstremalną, ekspedycję „Riese” oraz edukacyjną przeznaczoną dla dzieci. W podziemiach utworzono liczne wystawy tematyczne, między innymi "Zabezpieczenie obiektów podziemnych", "Nietoperze Podziemnego Miasta”, „Wyposażenie żołnierzy podczas walk na froncie". W odległości około $400 \mathrm{~m}$ od wlotów sztolni wybudowano płatny parking dla samochodów osobowych i autokarów oraz budynek obsługi zwiedzających (RZECZYCKI 2012). Ze względu na geologiczną atrakcyjność możliwe jest stworzenie w obiekcie podziemnej trasy geoturystycznej ukazującej typowe odmiany litologiczne oraz elementy techniki górniczej (ZAGOŻDŻON, ZAGOŻDŻON 2013, s. 23). Zarządcą trasy turystycznej jest jednostka organizacyjna Gminy Głuszyca funkcjonująca jako jednoosobowa spółka z ograniczoną odpowiedzialnością.

Trzecim z obiektów „Riese”, w którym utworzono w 2004 roku podziemną trasę turystyczną jest Centrum Muzealno-Turystyczne "Olbrzym” (,Włodarz"), zlokalizowane w lesie, na południe od wsi Jugowice. Jest to największy z obiektów. Łączna długość podziemnych wyrobisk wynosi 
3000 m. W środku zaaranżowano salę kinową, przygotowano wystawy narzędzi górniczych, natomiast na zewnątrz urządzono ekspozycję sprzętu wojskowego oraz wybudowano drewniane budynki obsługi turystów. Czas zwiedzania wynosi około 60 minut, przy czym część zalanych wyrobisk zwiedza się przepływając je łodzią (RZECZYCKI 2012). Obiekt ten stanowi również najważniejsze zimowisko nietoperzy, bowiem leży na obszarze specjalnej ochrony siedlisk Natura 2000 PLH020071, Ostoja Nietoperzy Gór Sowich (ŚWIERKOSZ i in., red. 2012). Na początku 2003 roku Nadleśnictwo Wałbrzych, będące właścicielem terenu, ogłosiło przetarg na wynajem gruntu, na którym znajdują się cztery wyloty sztolni. Przetarg wygrało Centrum Muzealno-Turystyczne „Olbrzym” z Ludwikowic Kłodzkich. Właściciel przedsiębiorstwa M.K. Szpakowski w lutym 2003 roku stał się użytkownikiem terenu, podpisując umowę na czas nieokreślony (RZECZYCKI 2012).

Czwartym z obiektów wchodzących w skład kompleksu „Riese” są podziemia pod zamkiem Książ. Zostały tam wydrążone dwa systemy korytarzy i komór, leżących $15 \mathrm{~m}$ i $50 \mathrm{~m}$ poniżej poziomu dziedzińca głównego. W 1971 roku sztolnie zostały przejęte przez Instytut Geofizyki Polskiej Akademii Nauk, która zainstalowała w podziemiach urządzania geofizyczne. W 2005 roku udostępniono dla zwiedzających jedynie część górnego pozio$\mathrm{mu}$, tzw. -15. Zwiedzanie to połączone jest z trasą zwiedzania całego zamku (KRUSZYŃSKI 2008). Pod koniec 2015 roku, na mocy porozumienia zawartego pomiędzy gminą Wałbrzych a Polską Akademią Nauk, zamek Książ uzyskał zgodę na udostępnienie dla ruchu turystycznego reszty podziemi. Dodatkowym atutem podziemnej trasy turystycznej będą funkcjonujące od wielu lat obserwatoria geofizyczne Polskiej Akademii Nauk. Od 1991 roku obiekt funkcjonuje jako spółka z ograniczoną odpowiedzialnością, której założycielem i właścicielem jest gmina Wałbrzych (ŁUCZYŃSKI 2010).

Należy nadmienić, że zarządzające podziemnymi trasami przedsiębiorstwa oraz samorządowe instytucje kultury są bardzo mocno osadzone w realiach lokalnej gospodarki turystycznej. Tym samym udostępnienie turystyczne podziemi przynosi wymierne korzyści ekonomiczne obszarowi o niewielkiej jak dotąd skali inwestycji turystycznych i o wysokiej stopie bezrobocia, wpływając niewątpliwie na zmianę profilu działalności gmin¹, na terenie których się znajdują.

${ }^{1} \mathrm{~W}$ latach 90. XX w. doszło do całkowitej likwidacji przemysłu weglowego w Wałbrzychu, natomiast w Walimiu i Głuszycy niemal całkowicie zlikwidowano przemysł włókienniczy. 


\section{Legenda "złotego pociągu"}

"Złoty pociąg" to przypuszczalnie pociąg III Rzeszy, który między listopadem 1944 roku a końcem stycznia 1945 miał wyruszyć z Wrocławia w kierunku Wałbrzycha, jednakże na dworzec w Wałbrzychu nigdy nie dojechał. Prawdopodobnie pociąg ten miał zawierać złoto, kosztowności oraz dzieła sztuki zrabowane przez hitlerowców w Polsce i Związku Radzieckim lub też tajne archiwa III Rzeszy (DZIKOWSKA 2015). Wprawdzie samo istnienie pociągu nigdy nie zostało oficjalnie potwierdzone, to jednak powstała wokół niego legenda stała się inspiracją dla licznych poszukiwań.

Jedną z pierwszych i najważniejszych osób, które przyczyniły się do poszukiwań owego pociągu, był wałbrzyszanin T. Słowikowski. Według jego opisu, tuż po zakończeniu wojny kilku Niemców pozostałych na terenie Wałbrzycha pracowało na kolei, natomiast jeden z nich odnalazł wejście do ukrytego we wzgórzu, niedaleko linii kolejowej Wrocław-Wałbrzych, zamkniętego tunelu. Jednakże w obawie przed utratą życia, odkrywca nikomu nie powiedział o znalezisku. Prawdopodobnie dopiero na łożu śmierci przekazał informacje o tunelu mężczyźnie o nazwisku Schulz, ów człowiek poinformował o tym T. Słowikowskiego, który od tamtego czasu rozpoczął własne badania w sprawie ukrytego pociągu. W 2003 roku wałbrzyszanin zgłosił wyniki swojego dochodzenia władzom państwowym i otrzymał zezwolenie na rozpoczęcie badań terenowych, ale z powodu niedotrzymania formalności związanych z pozwoleniem na prace budowlane, badania musiano przerwać (WIGHT 2015).

Ponowny przełom $\mathrm{w}$ poszukiwaniach nastąpił 18 sierpnia 2015 roku, gdy P. Koper oraz A. Richter wskazali władzom miasta Wałbrzych hipotetyczne miejsce ukrycia pociągu. Według nich 150-metrowy skład został ukryty między 60. a 65. kilometrem trasy kolejowej nr 274 Wrocław-Wałbrzych, nieopodal stacji Wałbrzych Szczawienko i zamku Książ. Informacja ta bardzo szybko przeniknęła do mediów nie tylko ogólnopolskich, ale i zagranicznych. Domniemane odkrycie zwróciło uwagę m.in. brytyjskiej prasy "The Telegraph", „The Guardian” oraz telewizji BBC, „Sky News", niemieckiego dziennika "Die Welt”, tygodnika "Stern” oraz telewizji „Deutsche Welle”, amerykańskich telewizji informacyjnych CNN, „Fox News” oraz australijskiego portalu news.au.com („Wprost" 2015). Ponadto informacja ta przyczyniła się do nagłego wzrostu turystów pragnących ujrzeć na własne oczy prawdopodobne miejsce ukrycia nazistowskiego pociągu oraz podziemia wydrążone w czasie II wojny światowej. 


\section{Wpływ analizowanego wydarzenia na ruch turystyczny}

Pragnąc osiągnąć przyjęty cel badania, pozyskano informacje dotyczące liczby osób zwiedzających Sztolnie Walimskie oraz zamek Książ w układzie rocznym i miesięcznym. Dane statystyczne obejmowały lata 2001-2015. Dla Podziemnego Miasta Osówka oraz Centrum Muzealno-Turystycznego „Olbrzym" nie są prowadzone tak szczegółowe statystyki ruchu turystycznego.

Na podstawie danych statystycznych z lat 2001-2015, zaprezentowanych na rys. 1 można zauważyć, że Sztolnie Walimskie przyciągają kilkadziesiąt tysięcy turystów rocznie. Od początku XXI wieku do 2014 roku obserwuje się niewielkie spadki liczby odwiedzających, z wyjątkiem lat 2003, 2007 i 2008. Przyczyn owego spadku można dopatrywać się w otwarciu w 2004 roku Centrum Muzealno-Turystycznego „Olbrzym”, niewystarczającej promocji obiektu w mediach ogólnopolskich oraz zagranicznych w zmniejszonej liczbie wycieczek szkolnych spowodowanej biurokratycznymi utrudnieniami przy ich organizowaniu oraz zmianie charakteru tychże wyjazdów, które coraz częściej organizowane są przez wyspecjalizowane biura podróży. W analizowanym okresie, to właśnie w 2015 roku odnotowano największą liczbę turystów - 51872 osoby; więcej w stosunku do roku 2014 o 11610 turystów (wzrost o $28,84 \%$ ).

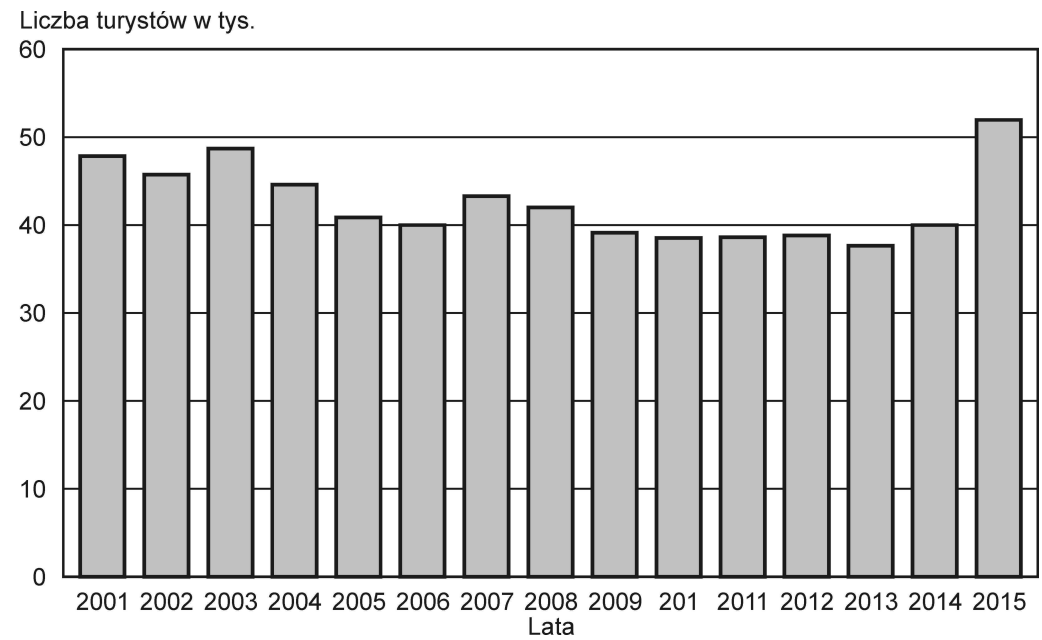

Rys. 1. Wielkość ruchu turystycznego w Sztolniach Walimskich w latach 2001-2015 Źródło: opracowanie własne na podstawie danych udostępnionych przez Dyrekcję Centrum Kultury i Turystyki w Walimiu 
Analizując zmiany liczby turystów w Sztolniach Walimskich w poszczególnych miesiącach drugiego kwartału lat 2001-2015, przedstawione na rys. 2 można zauważyć, że to właśnie w sierpniu Sztolnie Walimskie są najchętniej odwiedzane przez turystów. Miesiąc ten można uznać za tzw. sezon letni w Górach Sowich. Biorąc pod uwagę fakt, że informacja o rzekomym odkryciu "złotego pociągu" przedostała się do mediów w drugiej połowie sierpnia, w omawianym miesiącu 2015 roku obiekt zwiedziło 10803 osoby, czyli o 2378 turystów więcej niż w sierpniu 2014 roku (wzrost o 28,22\%). Wyraźny wzrost odnotowano także we wrześniu 2015 roku. W analizowanym miesiącu zanotowano 5299 osób, o 2373 zwiedzających więcej niż we wrześniu roku poprzedniego (wzrost o $81,10 \%$ ).

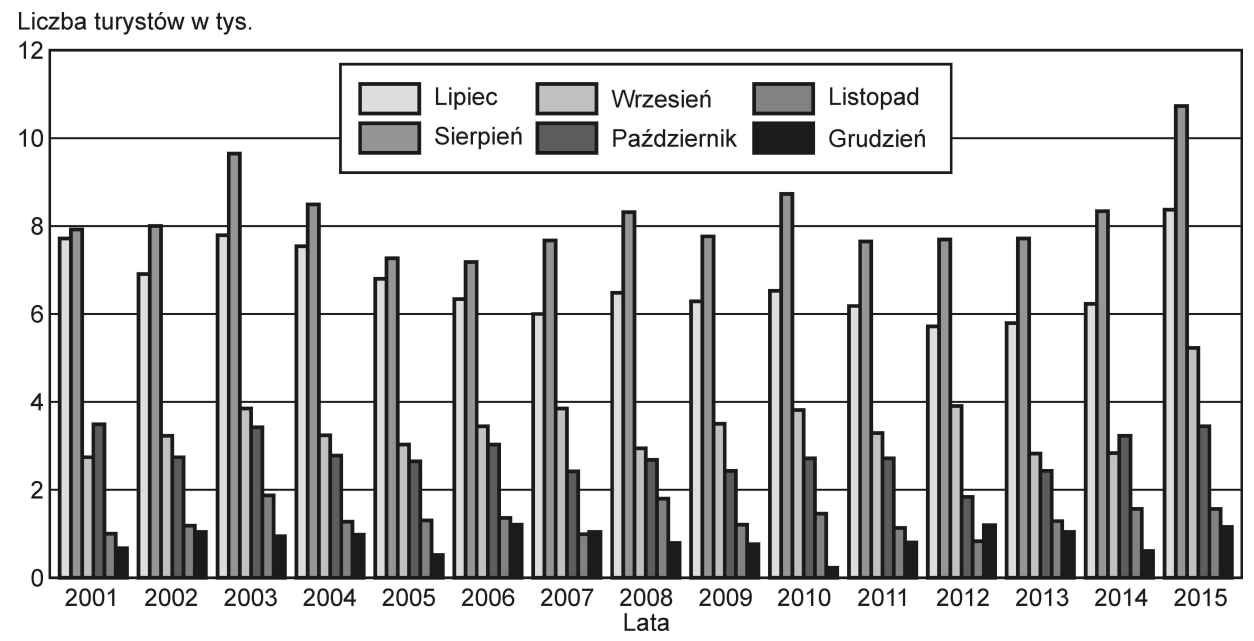

Rys. 2. Wielkość ruchu turystycznego w Sztolniach Walimskich według miesięcy drugiego półrocza w latach2001-2015

Źródło: opracowanie własne na podstawie danych udostępnionych przez Dyrekcję Centrum Kultury i Turystykiw Walimiu

Śledząc wielkość ruchu turystycznego w zamku Książ w latach 2001 -2015, ukazaną na rys. 3, zauważa się, że liczba zwiedzających jest zdecydowanie większa niż w Sztolniach Walimskich. Wynosi kilkaset tysięcy turystów rocznie. Przyczyn owego stanu rzeczy należy upatrywać w intensywnej promocji Książa w mediach ogólnopolskich. Jednakże, tak jak w Sztolniach Walimskich, to właśnie w 2015 roku zamek odwiedziło najwięcej turystów 287482 osoby. Był to w porównaniu do roku 2014 wzrost o 15600 osób 
(5,74\%). Warto zaznaczyć, że wzrost ruchu turystycznego przekłada się na wynik finansowy, który w 2015 roku według Zarządu Zamku Książ w Wałbrzychu sp. z o.o. wyniósł około $1 \mathrm{mln}$ zł. Pieniądze te zostaną przeznaczone, tak jak w latach ubiegłych, na kolejne inwestycje w zamku, dzięki czemu zostanie odciążony budżet gminy Wałbrzych.

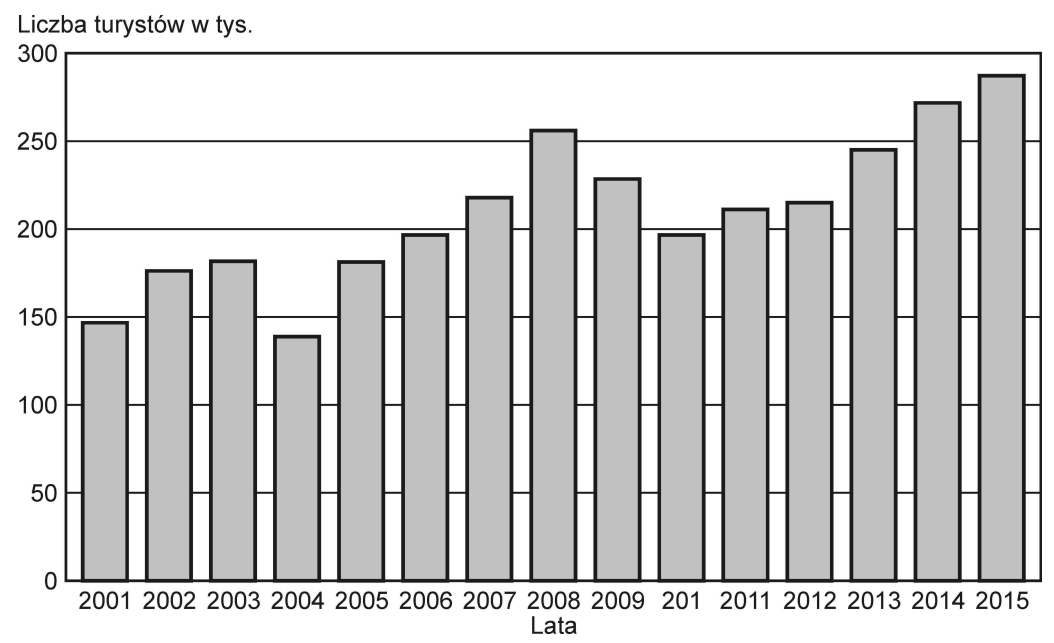

Rys. 3. Wielkość ruchu turystycznego w zamku Książ w latach 2001-2015 Źródło: opracowanie własne na podstawie danych udostępnionych przez zamek Książ w Wałbrzychu sp. z o.o.

Na podstawie danych statystycznych z drugiego półrocza z lat 20012015, zaprezentowanych na rys. 4, można zauważyć, że analogicznie jak w Sztolniach Walimskich, Książ odnotowuje najwięcej turystów w sierpniu². W miesiącu tym w 2015 roku obiekt zwiedziło 54806 osób, o 1715 więcej niż w roku poprzednim (wzrost o 3,23\%). Największy wzrost w stosunku do roku 2014 zanotowano we wrześniu - o 39,62\% oraz w grudniu - aż o $126,43 \%$.

Wpływ na wzrost frekwencji w 2015 roku miało kilka czynników. Niewątpliwie najważniejszym była informacja dotycząca "złotego pociągu" i ogromne zainteresowanie turystów tajemnicami II wojny światowej. Nie bez znaczenia dla wzrostu ruchu turystycznego są również inwestycje reali-

${ }^{2} \mathrm{~W}$ pierwszym półroczu największą frekwencję Zamek Książ odnotowuje w maju, kiedy na terenie obiektu odbywa się coroczny Festiwal Kwiatów. 
zowane od wielu lat w Książu oraz utworzenie wspólnego biletu wstępu do zamku i pobliskiej palmiarni.

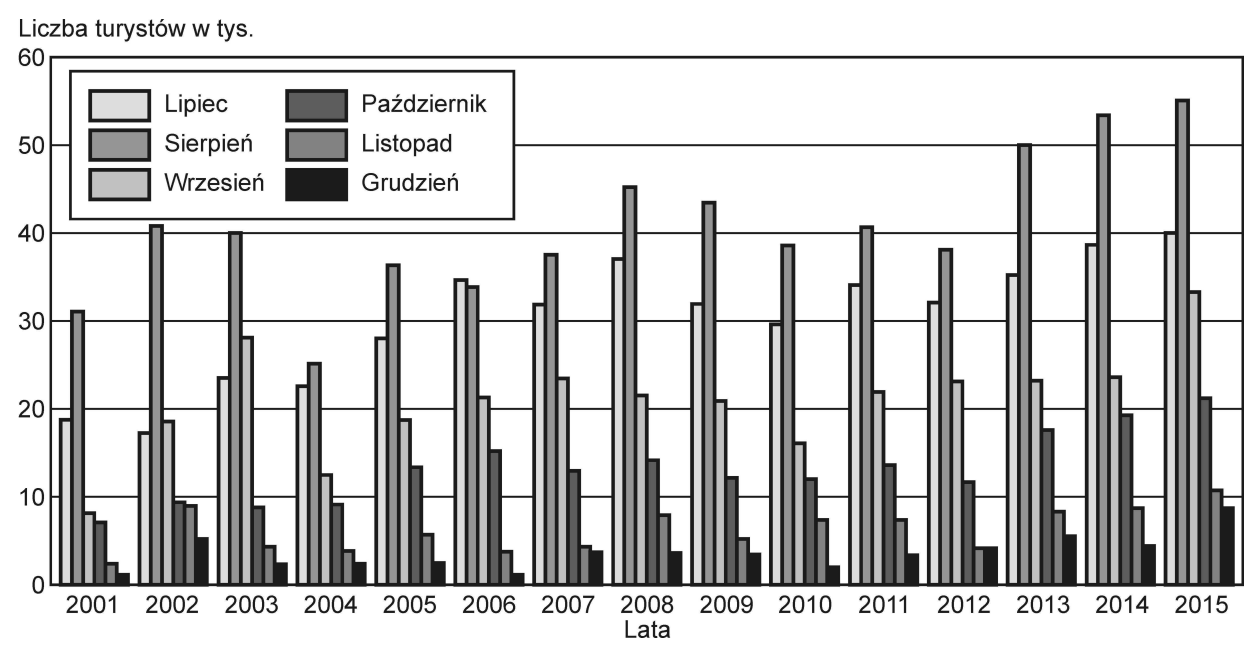

Rys. 4. Wielkość ruchu turystycznego w zamku Książ według miesięcy drugiego półrocza w latach 2001-2015

Źródło: opracowanie własne na podstawie danych udostępnionych przez zamek Książ w Wałbrzychu sp. z o.o.

Zarząd zamku Książ w Wałbrzychu sp. z o.o. zachęcony wzrostem ruchu turystycznego, tak jak wspomniano na początku opracowania, zamierza w 2016 roku udostępnić zwiedzającym całość podziemi wydrążonych pod zamkiem. Podziemna trasa turystyczna ma zostać utworzona we współpracy Książa z Państwową Akademią Nauk oraz Muzeum Gross-Rosen z Rogoźnicy, gdyż to właśnie więźniowie niemieckiego obozu koncentracyjnego KL Gross-Rosen w latach 1944-1945 drążyli podziemia pod zamkiem (SULA 2003).

Warto nadmienić, iż 29 sierpnia 2015 roku rozpoczęło się wspólne przedsięwzięcie promocyjne Centrum Nauki i Sztuki Stara Kopalnia, zamku Książ oraz Miasta Wałbrzych pod nazwą „Wałbrzych - Explore Wałbrzych”. Tak przygotowana tzw. złota oferta wizyt w Wałbrzychu jest skierowana do polskich, ale przede wszystkim zagranicznych turystów. Propozycja składa się $\mathrm{z}$ weekendowych pakietów pobytowych $\mathrm{w}$ Wałbrzychu, $\mathrm{w}$ ramach których przybywający turyści mają zapewniony transfer $\mathrm{z}$ wrocławskiego lotniska, a następnie przez trzy dni mają szansę uczestniczyć w: nocnym 
zwiedzaniu zamku Książ, wejściu do podziemi w centrum Wałbrzycha, do Starej Kopalni czy Podziemnego Miasta Osówka, jak również zwiedzić uzdrowisko Szczawno-Zdrój.

Ideą przedsięwzięcia jest przyciągnięcie do Wałbrzycha możliwie najszerszego grona gości ze świata, aby mogli poznać Wałbrzych, jako miasto tajemnic II wojny światowej, o którym po raz pierwszy usłyszeli w kontekście informacji o odnalezieniu zaginionego, nazistowskiego pociągu pancernego.

\section{Wnioski}

Przeprowadzona analiza pozwala na sformułowanie następujących wniosków:

1. Zależność między nagłośnieniem informacji o rzekomym odnalezieniu pancernego pociągu z II wojny światowej a wzrostem ruchu turystycznego w Wałbrzychu i okolicach jest zauważalna. Porównując liczbę turystów w latach 2014 i 2015, odnotowano wzrost zwiedzających w Sztolniach Walimskich w Rzeczce o 28,84\%, natomiast w zamku Książ w Wałbrzychu o $5,74 \%$.

2. Jednocześnie wzrost ruchu turystycznego przekłada się na zwiększenie dochodów podmiotów z branży turystycznej prowadzących działalność gospodarczą w Wałbrzychu i okalających go gminach.

3. Innym następstwem medialnego szumu jest sposobność wypromowania destynacji i jej oferty, jak również wykreowanie nowego wizerunku miejsca docelowego: „z dawnego miasta górniczego do turystycznego Wałbrzycha".

4. W celu utrzymania wzmożonego zainteresowania turystów kierownictwo zamku Książ planuje udostępnić w maju 2016 roku dwa poziomy podziemi wydrążonych pod Książem, w ramach projektu „Riese”.

5. Ponadto, aby podtrzymać zainteresowanie zwiedzających, władze Wałbrzycha, okolicznych gmin oraz gestorzy podziemnych tras turystycznych mogą opracować nowy, wspólny produkt turystyczny w formie szlaku turystycznego dla turystów zmotoryzowanych wokół „Riese”, począwszy od Muzeum Gross-Rosen w Rogoźnicy, przez podziemia zamku Książ, pałacyk w Jedlince, w którym mieściła się siedziba generalnej dyrekcji budowy, a skończywszy na podziemiach w Górach Sowich. Szlak ten po- 
zwoliłby na dokładne zapoznanie się z historią kompleksu „Riese”, natomiast wspólny bilet wstępu zachęciłby turystów do zwiedzenia wszystkich funkcjonujących podziemnych tras turystycznych.

6. W porównaniu do innych podziemnych tras turystycznych w Polsce kompleks "Riese" łączy w sobie zarówno elementy historii, geologii oraz techniki budowlanej i górniczej, a to wszystko zostało osadzone w atmosferze tajemnicy i stanowi o jego atrakcyjności.

\section{Bibliografia}

AWEDYK M., 2015, Wielodyscyplinarne planowanie turystyczne w kontekście badań nad przyszłościa, [w:] M. Makowska-Iskierka (red.), Badania nad turystyką. Jeden cel różne podejścia, ser. „Warsztaty z Geografii Turyzmu", t. 6, Wyd. Uniwersytetu Łódzkiego, s. 25-35.

CERA J., 1998, Tajemnice Gór Sowich, Inter Cera, Kraków, s. 79-80.

DEREK M., KOWALCZYK A., SWIANIEWICZ P., 2005, Wptyw turystyki na sytuację finansowa i rozwój miast w Polsce (na przykładzie miast średniej wielkości), „Prace i Studia Geograficzne”, 35, s. 199-217.

DZIKOWSKA J., 2015, Złoty pociag spod Wałbrzycha. Co w nim jest?, http://wroclaw.wyborcza.pl/wroc law/1,35771,18610908,zloty-pociag-spod-walbrzycha-co-w-nim-jest-historia.html, 18.02.2016.

GAWORECKI W.W., 2010, Turystyka, PWE, Warszawa.

KRUSZYŃSKI P., 1998, Podziemia w Górach Sowich i zamku Książ, Państwowe Muzeum Gross-Rosen, Wałbrzych.

KRUSZYŃSKI P., 2008, Wojenne tajemnice zamku Książ. Podziemia, Wyd. Rotoryf, Świdnica.

ŁUCZYŃSKI R.M., 2010, Losy rezydencji dolnośląskich w latach 1945-1991, Oficyna Wydawnicza Atut, Wrocław, s. 220-278.

PANASIUK A., 2006, Ekonomika turystyki, PWN, Warszawa.

RZECZYCKI T., 2012, Podziemne trasy turystyczne Polski. Obiekty strategiczne, Technol, Kraków, s. 70114.

Sula D., 2003, Arbeitslager Riese. Filia KL Gross-Rosen, Muzeum Gross-Rosen, Rogoźnica, s. 15-19.

ŚWIERKOSZ K., LIBERACKA H., ŁYSIAK M., ZAJĄC K. (red.), 2012, Obszary Natura 2000 na Dolnym Ślą$s k u$, Regionalna Dyrekcja Ochrony Środowiska, Wrocław.

WIGHT E., 2015, A family brutally murdered, secret police threats and deadly booby traps: Treasure hunter who spent 40 years searching for Nazi gold train reveals its dark secrets, http:/ / www.dailymail.co. uk/news/article-3216741/A-family-brutally-murdered-secret-police-threats-deathbed-confess ion-Treasure-hunter-spent-40-years-searching-Nazi-gold-train-reveals-dark-secrets.html\#ixzz 41gitDF8w, 01.03.2016.

http:/ / www.wprost.pl/ar/518654/Swiatowe-media-pisza-o-zlotym-pociagu-Wzmianki-nawetwAustralii/18.02.2016. 